\title{
Comparison of Prairie and Eroded Agricultural Lands on Soil Organic Carbon Retention (South Dakota)
}

\author{
K. R. Olson ${ }^{*}$, A. N. Gennadiyev ${ }^{2}$, R. G. Kovach ${ }^{2}$, T. E. Schumacher ${ }^{3}$ \\ ${ }^{1}$ Department of Natural Resources and Environmental Science, University of Illinois at Urbana-Champaign, \\ Urbana, USA \\ ${ }^{2}$ Faculty of Geography, Lomonosov Moscow State University, Moscow, Russia \\ ${ }^{3}$ Plant Science Department, South Dakota State University, Brookings, USA \\ Email: krolson@illinois.edu
}

Received 5 March 2014; revised 5 April 2014; accepted 12 April 2014

Copyright $@ 2014$ by authors and Scientific Research Publishing Inc.

This work is licensed under the Creative Commons Attribution International License (CC BY). http://creativecommons.org/licenses/by/4.0/

(c) (i) 0 pen Access

\section{Abstract}

The primary objective of this research was to predict changes in soil organic carbon (SOC) and total soil nitrogen (TSN) stocks as a result of land use change from prairie to agricultural land if the mesic-frigid temperature line moved north in the US and the former frigid soils were cultivated. The conversion of prairie to agricultural use, as a result of climate shift, would release SOC to atmosphere and enhance greenhouse gas emissions. The SOC and TSN differences between the prairie site and agricultural land were compared in South Dakota. The agricultural land had $18 \%$ less SOC and 16\% less TSN or only half of the expected loss from prairie levels. An attempt was made to document the land use history of the prairie site to understand why SOC and TSN losses were less than anticipated. The fly ash concentration levels on prairie side slopes suggested that the prairie was historically disturbed and eroded. Intensive grazing and burning contributed to the disturbance. The SOC and TSN stock losses appear to represent the minimal change that would occur in the next 100-year time period if a prairie was shifted to agricultural use as a result of climate shift and the mesic-frigid temperature line in US was to move north.

\section{Keywords}

Soil Organic Carbon, Fly Ash, Erosion, Prairie, Cultivation, Grazing

\footnotetext{
${ }^{*}$ Corresponding author.
}

How to cite this paper: Olson, K.R., Gennadiyev, A.N., Kovach, R.G. and Schumacher, T.E. (2014) Comparison of Prairie and Eroded Agricultural Lands on Soil Organic Carbon Retention (South Dakota). Open Journal of Soil Science, 4, 136-150. http://dx.doi.org/10.4236/ojss.2014.44017 


\section{Introduction}

Conversion of prairie to agricultural use would reduce carbon stored in the soil and an increase in $\mathrm{CO}_{2}$ released to the atmosphere. This change would result in reduced carbon inputs to the soil and the accelerated decomposition SOC [1] [2]. Erosion removes SOC from the original site of formation and increases its burial in depositional soil environments. The net release of carbon to atmosphere from the soil is affected by: 1) replacement of SOC at eroding sites as a result of plant inputs; 2) decrease in SOC available for decomposition at the less productive eroding site [3]; 3) deep placement of carbon and inhibited decomposition especially if conditions are anaerobic [3], and [4] enhanced decomposition of SOC as a result of physical and chemical breakdown of soil during detachment and transport [5].

Gregorich et al. [5] found most soils undergo about a $20 \%$ to $30 \%$ loss of soil organic carbon (SOC) by mineralization and decomposition when they are brought under dryland cultivation. In addition, even greater SOC losses and gains may occur as a result of wind and water erosion, transport and deposition. Vanden Bygaart et al. [6] suggested that past erosion, transport and deposition have resulted in redistribution of SOC in the landscape and have yet to be fully considered in the study of SOC dynamics and the potential for C sequestration in agricultural soils. Janzen et al. [7] monitored the change in SOC stock over time and found soil management practices to be critical to understanding sequestration of $\mathrm{C}$ from atmosphere in agricultural soils. In southern Ontario, VandenBygaart et al. [8] measured the changes in SOC after 15 years of NT and found when the entire soil profile was considered there was more loss of SOC stocks than gains. Vanden Bygaart et al. [8] found that climate, management history, and soil type and soil landscape process affected the SOC dynamics under NT.

The SOC stock dynamics are affected by land use, tillage, no-tillage, soil erosion, transport and depositional processes [9] [10]. Shukla and Lal [11] showed that erosion decreased soil organic carbon stock of Ohio soils. In Canadian prairie studied by Tiessen et al. [12], McGill et al. [13], Janzen et al. [7] and Bowman et al. [14] they found that soils have lost $30 \%$ to $35 \%$ or more of their C due to farming. Malhi et al. [15] reported that soil under permanent grass or hayland cover contained substantially higher SOC stocks than that when soil was tilled for annual grain crops.

Grassland and forest soils tended to lose $20 \%$ to $50 \%$ of the original SOC stock in the tilled layer (15 - $20 \mathrm{~cm})$ within the first 40 to 50 years of cultivation [12] [16]-[22]. Oxidation of SOC stock and emission of $\mathrm{CO}_{2}$ to the atmosphere occurred as a result of plowing. Aeration as a result of land drainage of poorly drained and nearly level soils and erosion of well drained sloping soils often resulted in greater rates of oxidation of SOC and increased emission of $\mathrm{CO}_{2}$ to the atmosphere. Kern [23] estimated the historical SOC stock losses in the surface $30 \mathrm{~cm}$ after cultivation for major field crops in the contiguous U.S. to be $16 \%$ primarily as a result of the plowing which caused oxidation of SOC and emissions of $\mathrm{CO}_{2}$ to the atmosphere.

Soil erosion rates can be determined by landscape segment once the landscape, historical soil management, and land use are known. Lal et al. [24] estimated the SOC stock of the sediment displaced by cropland erosion would result in $70 \%$ of SOC being re-deposited on lower landscape positions, $20 \%$ of SOC in sediment being emitted to atmosphere as $\mathrm{CO}_{2}$ and $10 \%$ of SOC being transported to ocean and other aquatic ecosystems. Van Oost et al. [3] examined the fate of the SOC exported from eroded watersheds. They found that 53\% to $95 \%$ of the eroded carbon was retained and re-deposited within the watershed land unit.

Growing concern about greenhouse gas emission and potential to impact climate has resulted in many attempts to reduce greenhouse gas emission by storing in the forest or prairie. Carbon can be sequestered in trees, below ground roots, in wood products and in the soil humus or soil organic matter as SOC and TSN. If the $\mathrm{CO}_{2}$ and $\mathrm{N}_{2} \mathrm{O}$ gases are removed from the atmosphere by trees or prairie plants and stored in the soil humus, it is referred to as SOC and TSN sequestration.

Agricultural, prairie, range, pasture and forest soils are some of the largest SOC storage reservoirs. Efforts should focus on increasing SOC stocks in these areas [25]. The Kyoto Protocol recognized that net emissions of greenhouse gases, such as $\mathrm{CO}_{2}, \mathrm{~N}_{2} \mathrm{O}$ and $\mathrm{CH}_{4}$, can be decreased either by reducing emissions and/or increasing the rate of $\mathrm{C}$ sequestration in soil.

Water and wind erosion can impact the soil which serves as a source or sink of $\mathrm{CO}_{2}, \mathrm{~N}_{2} \mathrm{O}, \mathrm{CH}_{4}$, and other greenhouse gases, depending on soil productivity and the predominant pedospheric processes [4] [14] [26]. Erosion can deplete on-site SOC, transporting dissolved organic C (DOC) in runoff water and particulate organic carbon (POC) in eroded sediments to receive environments. However, the processes involved are not well documented. Globally, C loss from erosion is estimated to be 150 to 1500 million tons per year [4] [5] [26]. 
Depending on the landscape position, water eroded soil particles move down-slope and may be stored in lower sections of the same field or watershed for long periods of time. The sediment redistribution increased spatial variability of soil properties across landscapes, including SOC and TSN [27] [28]. Some of the eroded soil particles are transported into aquatic ecosystems and bottomland depressions where SOC stock may be retained. Annual atmospheric emission of $C$ caused by wind and water erosion is estimated to be as much as $15 \mathrm{TgC} / \mathrm{y}$ in the U.S. and $1 \mathrm{PgC} / \mathrm{y}$ in the world [4]. Although erosion is likely to reduce crop productivity, other estimations suggest that soil erosion could contribute to a net sink for C [4]. However, the authors point out that the effects of climate change on the long term stability of buried sediments are unknown and could change simulation results. Land cover and use changes, such as conversion of wetlands into farmland, are examples of climate shift effects that could oxidize relic soil carbon stored in eroded landscapes.

In the Northern Great Plains, soil productivity and SOC stocks are substantially lower than what they are when the original prairie sod was first cultivated [29]. Soil properties in cultivated fields have been modified significantly by a combination of accelerated erosion processes, including tillage, water, and wind erosion events [30] [31]. This has resulted in less than ideal growing conditions at almost all topographic positions in a rolling landscape (crests, shoulders and backslope positions) and substantial losses in SOC [27]. In some cases, the severe erosion has caused the topsoil in deposition zones to reflect the original subsoil of the upper slope [32].

Fly-ash has been used as a time marker in both upland erosion and bottomland depositional studies [33]-[37]. The distribution of fly-ash incidence in soil columns [9] [33] [36]-[38] has been shown to provide useful information regarding pedoturbation of subsurface horizons since settlement.

Olson et al. [38] determined the cropland landscape retained 52 percent of the total SOC of the woodland on a mass basis after 150 years of agricultural use. The causes of the 48 percent reduction in SOC included land use change, tillage, mixing, fertilization, and soil erosion. The amounts of SOC retained on both landscapes were significantly different. The agricultural land had significantly lower SOC levels in both the surface and subsurface layers.

Olson et al. [39] determined the soil erosion rates in cropland of west central Illinois using a magnetic tracer (fly ash) and radio-cesium (cesium-137). The cesium-137 and fly ash data suggest that cropland lost significant sediment, fly ash and cesium-137 to erosion process especially from the upper and lower backslopes and footslope. The fly ash and cesium-137 determined erosion amounts and annual soil erosion rate for cropland landscapes positions were the highest for the upper and lower backslopes. Past backslope annual erosion rates for three different time periods were $51 \mathrm{Mt} \mathrm{ha}^{-1} \mathrm{yr}^{-1}$ or less and above the tolerable soil loss rate of $11 \mathrm{Mt} \mathrm{ha}^{-1} \mathrm{yr}^{-1}$ for Hickory soils.

The primary objectives of this research were: 1 ) determine the land use from 1851 to present on the Sioux Prairie transect area; 2) verify that the prairie was never cultivated; 3 ) determine the effects of land use conversion from prairie to eroded row cropland on the SOC and TSN sequestration, net storage, retention and loss from the tilled layer and subsoil; and 4) predict changes in SOC and TSN stocks of uncultivated prairie soils if the former frigid soils were cultivated.

\section{Methodology and Activities}

\subsection{Local Geology, Soils and Vegetation}

The Sioux Prairie is located at the southern end of a rolling highland called Prairie Coteau. This massive flatiron shaped plateau includes Sioux Prairie which is located about $16 \mathrm{~km}(10 \mathrm{mi})$ west of the Big Sioux River. The coteau west of the Big Sioux River drains into many lakes and potholes. The surficial features of the Sioux Prairie are typical of the rolling potholed coteau. End moraines running approximately north-south direction characterize most of the Sioux Prairie topography [40]. Most of the drainage is directed towards the southern and southeastern portions of the prairie where a wide horseshoe shaped wetland occurs. In addition, a number of small potholes collect runoff in the northern one-half and western edge of the Sioux Prairie including the transect site area. Surficial deposits on the Sioux Prairie consist primarily of glacial till and composed of heterogeneous materials ranging in size from clay particles to boulders with clay being the predominant particle size. This glacial till was deposited during the Wisconsin glacier stage, some 13,000 to 14,000 years ago.

The Sioux Prairie Conservancy (Longitude 96 degrees, 47.326 minutes west; Latitude 44 degrees, 01.793 minutes north) established in 1983 and the EcoSun Center (Longitude 96 degrees, 50.642 minutes west; Latitude 44 degrees, 01.466 minutes north) located near Colman, South Dakota was selected for soil sampling. The soils 
are now considered to be in temperature regime mesic and in the past they were frigid temperature. Before 1983, the soils at Sioux Prairie and EcoSun were mapped and classified as Vienna (Fine-loamy, mixed, superactive, frigid Calcic Hapludolls) and Parnell (Fine, smectitic, frigid Vertic Argiaquolls) soils. These soils were reclassified as Wentworth (Fine-silty, mixed, superactive, mesic Udic Haplustolls) and Whitewood (Fine-silty, mixed, superactive, mesic Cumulic Endoaquolls) (Figure 1).

Approximately 200 species of plants adorn Sioux Prairie in the springtime including the Pasque flower (Pulsatilla vulgaris), prairie smoke (Geum triforum) and gold flower of blue-eyed grass bespangle (Sisyrinchium bellum). The black-eyed Susans dot (Thunbergia alata) the prairie in summer. Autumn brings yellow goldenrods (Solidago genus), sunflowers (Helianthus annuus) and purple flowered asters (Aster tripolium) and ironweed (Vernonia altissima).

The Sioux Prairie and EcoSun sites were used to quantify the amount of SOC (Mg C ha $\left.{ }^{-1}\right)$ and TSN (Mg N $\mathrm{ha}^{-1}$ ) in humus or soil organic matter. This prairie area was not cultivated during the last 130 years but was pastured from 1945 to 1971 and burned periodically to control invasive plants. The nearby EcoSun site was used for agriculture including row crops for the previous 130 years. Transects were made of prairie landscapes with soils sampled by landscape position (interfluve, shoulder, backslope, footslope and toeslope), weighted by width of landscape position and determined for the entire landscape at the prairie and cropland sites. Soil erosion rates were determined for the prairie by measuring fly ash concentration levels within each landscape position. The bulk density of each soil layer and at each landscape position were determined, the SOC and TSN and the fly ash concentration of each layer was measured and expressed by volume. When past soil erosion and subsequent deposition occurred, the SOC and TSN rich sediment would changed the SOC, TSN and fly ash contents of each landscape position within a landscape limited the effect on the landscape SOC and TSN stocks since lower landscape positions collected most of the transported and deposited sediment.

\subsection{Field Sampling Procedures}

Soil samples will be collected from two transect observations (replications) spaced $10 \mathrm{~m}$ apart at each of the prairie and cropland landscape positions. The prairie and cropland transects were subdivided by landscape position resulting in samples being collected for each of the following landscape positions (interfluve, shoulder,

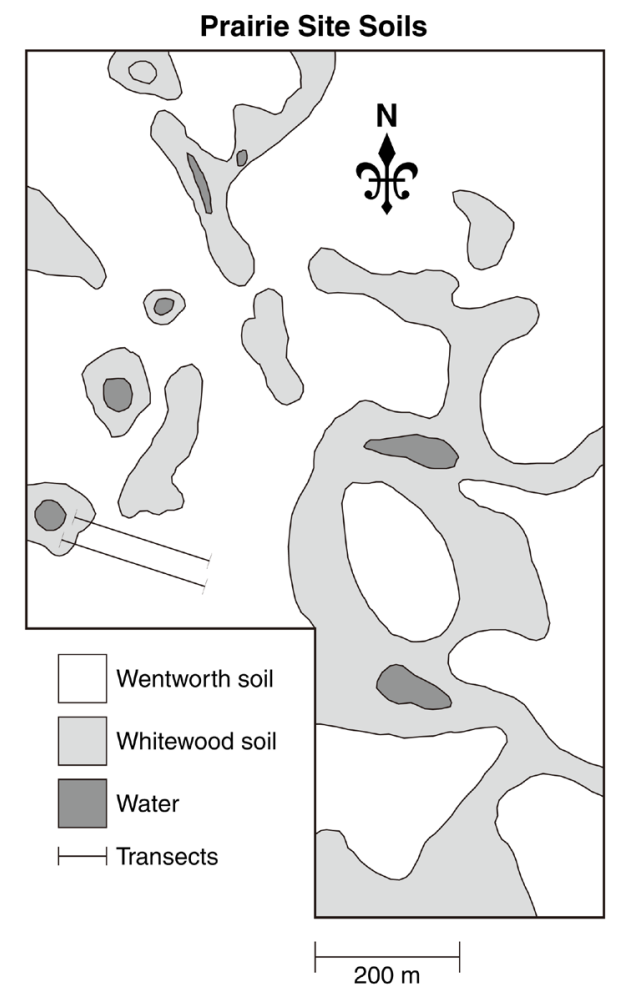

Figure 1. Soil map of prairie. 
backslope, footslope and toeslope) (Figure 2). Three 3.2-cm-diameter soil cores that were sampled $10 \mathrm{~m}$ apart at each transect point using hand soil push probe to a depth of $0.5 \mathrm{~m}$. The prairie soil cores were cut into three segments $(0-0.15,0.15-0.30$ and $0.30-0.50 \mathrm{~m})$ for the laboratory determinations. The EcoSun agricultural soil cores were separated into four segments $(0-0.15,0.15-0.30$ and $0.30-0.50 \mathrm{~m})$ for the laboratory analysis. Samples were analyzed separately by transect (2), depth (3), landscape position (5) and land use (2). Samples were dried at room temperature, sieved to pass a 2-mm sieve, and subsequently the SOC and TSN stocks were measured for 70 soil samples from both land uses at the two sites.

\subsection{Laboratory Procedures}

After removal of plant residue, SOC and TSN stocks were measured using the modified acid-dichromate organic carbon procedure number 6A1 [41]. Field moist core bulk density will be determined [41] using a Model 200 soil core sampler (5.6 cm diameter and $6 \mathrm{~cm}$ high) manufactured by Soil Moisture Equipment Corp (Goleta, California, USA). The bulk density values for each layer were used to convert the SOC on a concentration basis to a volumetric basis. The replicated SOC stock values were determined for each depth, landscape position and land use. The agricultural land SOC stock values from the 2 separate transects at both the prairie and cropland land use sites were determined and then compared for the same depth and landscape position at each site.

The magnetic minerals and fly-ash content were determined using procedures developed by Jones and Olson [42] and revised in Olson et al. [9] [10]. Fly-ash content was determined in the ferrimagnetic fraction of the sample. Sub-samples of fine-earth samples previous passed through a 2-mm sieve were ground to $<250 \mu \mathrm{m}$ in a mortar and pestle to pass a $0.250 \mathrm{~mm}$ sieve. Magnetic susceptibility was subsequently determined with a modified Gouy balance (model MK I \# 6632, Johnson Matthey Wayne, PA, USA).
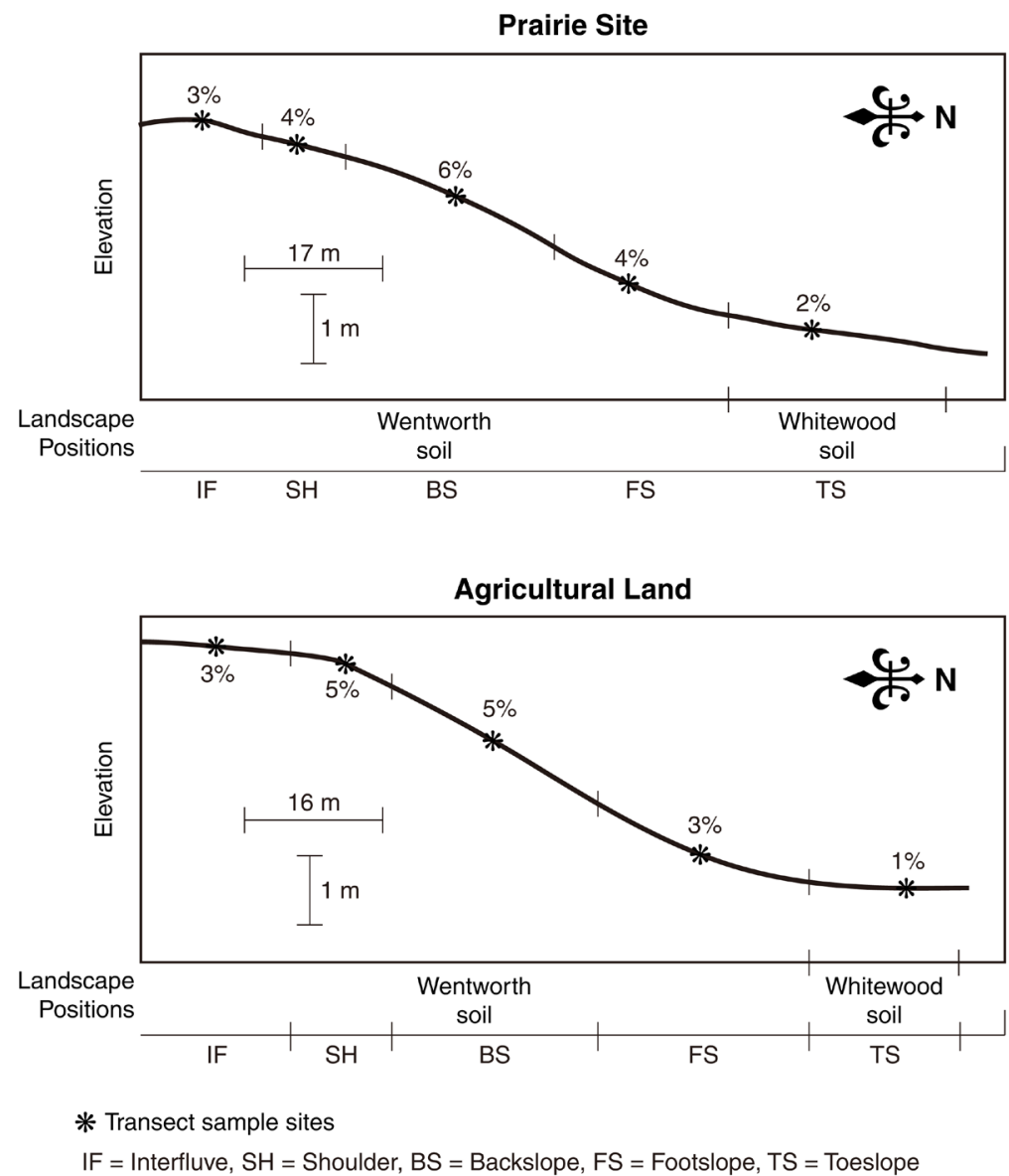

Figure 2. Cross section of prairie and agricultural land transects showing landscape positions, sampling sites, slope gradients and soils. 
The fly ash interfluve mean content for prairie was used as baseline to calculate erosion from prairie landscapes. The fly ash interfluve mean for cropland was used as baseline to calculate erosion from cropland landscape positions. The cropland toeslope continued to receive fly-ash rich sediment and fly ash was present to $0.50 \mathrm{~m}$ depth. When the cropland toeslope was sampled and totaled to $0.5 \mathrm{~m}$ the profile had more fly ash than the prairie $0-30$ $\mathrm{cm}$ layer which clearly showed deposition of fly ash rich sediment. All two cropland transects were tested separately so that a mean and SD by cropland landscape positions could be determined. The cropland landscape position fly ash mean and SD and also provided an indication of the natural variability in the fly-ash data.

The fly ash deposition time started in 1910 and stopped in 1960s but still remained as a time marker in the soils in 2011. This soil marker could be used to determine the amount of soil erosion and the rate for the last 100 years. Initially, the fly-ash method assessed the soil stability, soil erosion and sediment deposition situation during the last 100 years (based on time of coal fired locomotives).

\subsection{Statistical Methods}

Statistical analyses were performed using Statistical Analysis System (SAS) computer software [43]. A Least Significant Difference (LSD) procedure performed at the $\mathrm{P}=0.05$ level will be used to determine if there were significant SOC, TSN and fly ash concentration and stock differences between the prairie and agricultural land uses for the same landscape position and layer depth interval.

\section{Results and Discussion}

\section{Determination Land Use History of the Prairie site}

In 1851, the prairie site was part of the eastern South Dakota lands signed over to USA. The first European settlement in the area was in 1857 but was abandoned in 1858 due to an attack from Yankton Sioux. European settlement began again in 1872. In 1873 Moody County was organized. The first railroad to enter South Dakota was in 1872 at Yankton at the Southeast border of South Dakota and Nebraska. Colman (the nearest town to prairie) was founded in 1880 with post office starting in 1881. Based on biographical information from early settlers in Moody County it looks like most arrived in the late 1870s and early 1880s. South Dakota became a state in 1889. The state was surveyed and sections 16 and 36 were used for schools and other public purposes. Sioux Prairie is in section 36. These areas were known as common school lands. The prairie site was legally in the public lands and school lands, protected from private settlement from 1889 to 1945.

The 80 ha (200 ac) of Sioux Prairie land was sold in 1945 to Irving H. Kenison on October 24, 1945 by the state of South Dakota. On November 2, 1971 the prairie land was transferred to the Nature Conservancy. Between 1945 and 1970, the land was private holdings, and the entire area was managed as rangeland under both grazing and haying. During this time period, 8 ha $(20 \mathrm{ac})$ in the northwest corner (Figure 3) was plowed and now support an almost pure stand of smooth brome (Bromus inermis L.). In the spring of 1975, the 16 ha (40 ac) in the southwest corner (Figure 3) including the transect sites were burned resulting in a robust growth of Big bluestem (Andropogon gerardii Vitman) and other tall grasses. Some grazing occurred in 1975 as a result of a fence failure. However, by 1976 smooth brome regained a dominant appearance in the southwest forty. In August of 1978 a management plan for prairie was prepared. The plan written by Clair D. Welbon [44] of USDA, SCS recommended prescribed burning for the southwestern corner of prairie site (including our transect sites). The plan called for the burning each year from 1978 to 1982 and for heavy spring grazing to reduce competition from smooth brome and Kentucky bluegrass.

Table 1 provides the landscape position, land use, soil series and horizons sampled at the EcoSun sites. The soils are on similar slope gradients and on northwest facing slopes. Table 2 summarizes the SOC by landscape position at the prairie and agricultural land sites. The total SOC stock at each landscape position declined with depth even with the $30-50 \mathrm{~cm}$ layer being $5 \mathrm{~cm}$ thicker than other layers which increased total amount values by $30 \%$. At all 5 landscape positions the prairie site had more SOC stock in $0-50 \mathrm{~cm}$ layer than the cropland but only the shoulder and toeslope were statistically higher. The prairie interfluve had $12 \%$ more SOC, the shoulder had 57\% more, the backslope had $11 \%$ more SOC, the footslope $13 \%$ more SOC and the toeslope $36 \%$ more SOC.

The TSN data for the sloping prairie and the adjacent agricultural land is provided in Table 3. At all 5 landscape positions the prairie site had more TSN than the cropland but only the shoulder was statistically higher. The prairie interfluve has $14 \%$ more TSN, the shoulder had 28\% more TSN, the backslope had the same amount 
Prairie Site Vegetation

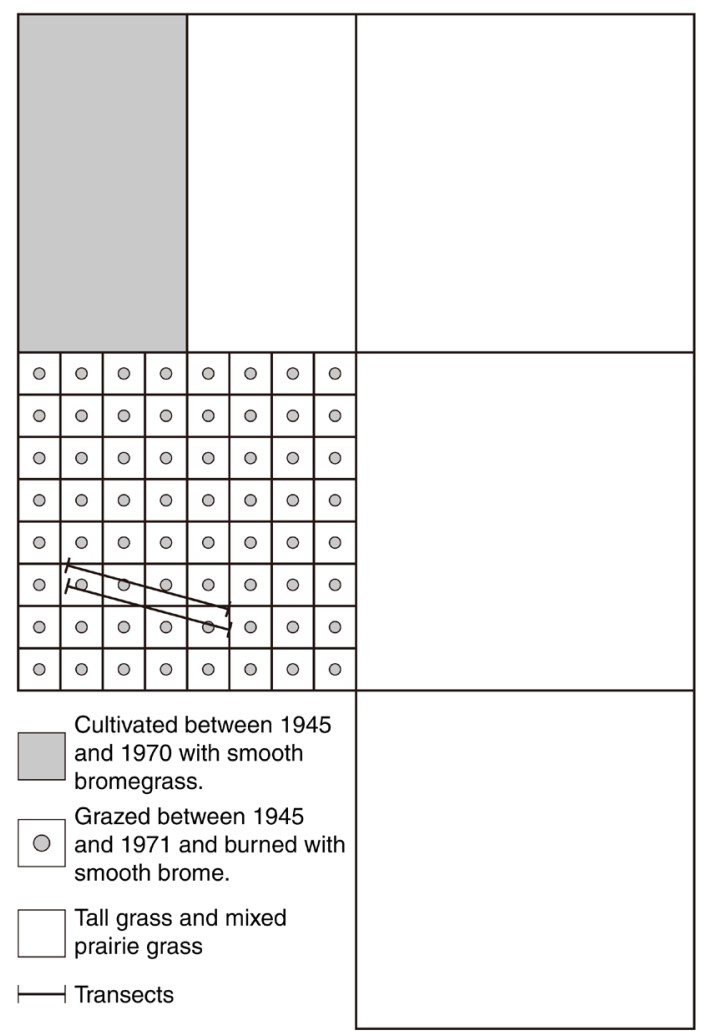

Figure 3. Area cultivated between 1945 and 1971 intensively grazed prairie area with smooth brome grass invading.

Table 1. Landscape position, vegetation, slope gradient, soils and soil horizons at Sioux Prairie and EcoSun, South Dakota sites.

\begin{tabular}{|c|c|c|c|c|c|c|c|c|}
\hline Transect & Landscape segment & Sampled & Slope & Slope & Soil & Vegetation & Cultivation & Soil \\
\hline & site no. & layer (m) & gradient (\%) & shape & series & & & horizon \\
\hline \multicolumn{9}{|c|}{ Sioux Prairie } \\
\hline SP1 & Interfluve & $0.0-0.5$ & 3 & linear & Wentworth & prairie & no & $\mathrm{A}, \mathrm{Bw}$ \\
\hline SP2 & Shoulder & $0.0-0.5$ & 4 & convex & Wentworth & prairie & no & $\mathrm{A}, \mathrm{Bw}$ \\
\hline SP3 & Backslope & $0.0-0.5$ & 6 & linear & Wentworth & prairie & no & $\mathrm{A}, \mathrm{Bw}$ \\
\hline SP4 & Footslope & $0.0-0.5$ & 4 & concave & Wentworth & prairie & no & $\mathrm{A}, \mathrm{Bw}$ \\
\hline SP5 & Toeslope & $0.0-0.5$ & 2 & linear & Whitewood & prairie & no & $\mathrm{O}$ \\
\hline \multicolumn{9}{|c|}{ EcoSun } \\
\hline ES1 & Interfluve & $0.0-0.5$ & 3 & linear & Wentworth & cropland & yes & $\mathrm{A}, \mathrm{Bw}$ \\
\hline ES2 & Shoulder & $0.0-0.5$ & 5 & linear & Wentworth & cropland & yes & $\mathrm{A}, \mathrm{Bw}$ \\
\hline ES3 & Backslope & $0.0-0.5$ & 5 & concave & Wentworth & cropland & yes & $\mathrm{A}, \mathrm{Bw}$ \\
\hline ES4 & Footslope & $0.0-0.5$ & 3 & linear & Wentworth & cropland & yes & $\mathrm{A}, \mathrm{Bw}$ \\
\hline ES5 & Toeslope & $0.0-0.5$ & 1 & concave & Whitewood & cropland & yes & $\mathrm{O}$ \\
\hline
\end{tabular}


Table 2. Summary of SOC stocks for the sloping prairie and the nearby cultivated cropland. Two pedons were sampled to a $0.5 \mathrm{~m}$ depth on each of five landscape positions on each transect.

\begin{tabular}{|c|c|c|c|c|}
\hline Depths & SOC (transect means) & SOC (transect means) & SOC difference & Percentage \\
\hline \multirow[t]{2}{*}{$\mathrm{cm}$} & Mg ha $^{-1}$ layer $^{-1}$ & Mg ha $^{-1}$ layer $^{-1}$ & Mg ha $^{-1}$ layer $^{-1}$ & change \\
\hline & Interfluve (prairie) & \multicolumn{2}{|c|}{ Interfluve (cropland) } & \\
\hline $0-15$ & $79.10 \mathrm{a}^{*}$ & $53.15 b$ & -25.92 & $-32 \%$ \\
\hline $15-30$ & $48.64 a$ & $47.43 a$ & -1.21 & $-2 \%$ \\
\hline $30-50$ & $27.72 \mathrm{a}$ & $35.50 \mathrm{~b}$ & 7.78 & $28 \%$ \\
\hline \multirow[t]{2}{*}{$0-50$} & $155.46 a$ & $136.09 a$ & -19.37 & $-12 \%$ \\
\hline & Shoulder (prairie) & Shoulder (cropland) & & \\
\hline $0-15$ & $78.28 \mathrm{a}$ & $44.61 b$ & -33.67 & $-43 \%$ \\
\hline $15-30$ & $58.86 a$ & $33.99 b$ & -24.87 & $-54 \%$ \\
\hline $30-50$ & $46.62 \mathrm{a}$ & $43.59 a$ & -3.03 & $-6 \%$ \\
\hline \multirow[t]{2}{*}{$0-50$} & $183.77 \mathrm{a}$ & $122.19 b$ & -68.58 & $-57 \%$ \\
\hline & Backslope (prairie) & Backslope (cropland) & & \\
\hline $0-15$ & 74.30a & $51.09 \mathrm{~b}$ & -23.21 & $-61 \%$ \\
\hline $15-30$ & $51.34 \mathrm{a}$ & $48.68 \mathrm{a}$ & -2.66 & $-5 \%$ \\
\hline $30-50$ & $40.85 a$ & $47.57 \mathrm{a}$ & 6.72 & $16 \%$ \\
\hline \multirow[t]{2}{*}{$0-50$} & $166.49 a$ & $147.34 a$ & -19.15 & $-11 \%$ \\
\hline & Footslope (prairie) & Footslope (cropland) & & \\
\hline $0-15$ & $65.21 \mathrm{a}$ & $62.49 a$ & -2.72 & $-4 \%$ \\
\hline $15-30$ & $56.82 \mathrm{a}$ & $49.10 \mathrm{a}$ & -7.72 & $-13 \%$ \\
\hline $30-50$ & $45.78 \mathrm{a}$ & $39.76 a$ & -6.02 & $-13 \%$ \\
\hline \multirow[t]{2}{*}{$0-50$} & $167.80 \mathrm{a}$ & 151.3a & -16.45 & $-13 \%$ \\
\hline & Toeslope (prairie) & Toesleope (cropland) & & \\
\hline $0-15$ & $86.41 \mathrm{a}$ & $41.06 \mathrm{~b}$ & -45.35 & $-52 \%$ \\
\hline $15-30$ & $43.92 \mathrm{a}$ & $34.17 \mathrm{~b}$ & -9.75 & $-22 \%$ \\
\hline $30-50$ & $42.56 a$ & $35.15 a$ & -7.41 & $-17 \%$ \\
\hline $0-50$ & $172.89 a$ & $110.38 b$ & -62.51 & $-36 \%$ \\
\hline
\end{tabular}

${ }^{*}$ Transect means for different land uses with the same letter and for the same landscape position and depth layer are not significantly different at the 0.05 probability level.

of TSN, the footslope $17 \%$ more TSN and the toeslope 15\% more TSN. The TSN changes were a little smaller than the SOC differences between the prairie and the cropland.

Table 4 weights the SOC by the landscape segment width. The prairie had $160.6 \mathrm{Mg} \mathrm{C}^{-1}$ and the agricultural land and had $29.0 \mathrm{MgC} \mathrm{ha}^{-1}$ or 18 less SOC. The SOC loss was thought to be caused by cultivation, tillage disturbance, and soil erosion. The $18 \%$ loss is more than expected for a prairie site so it was clearly intensively pastured and periodically burned from 1978 to 1983 . Consequently and land use change from prairie to cropland would result in SOC loss from storage and more greenhouse gas emissions. If only the eroding landscapes are included (interfluve, shoulder, backslope and footslope positions) the cropland would have lost $11 \%$ instead of $18 \%$ of SOC stock. 
Table 3. Summary of TSN stocks for the sloping prairie and the nearby cultivated cropland. Two pedons were sampled to a $0.5 \mathrm{~m}$ depth on each of five landscape positions on each transect.

\begin{tabular}{|c|c|c|c|c|}
\hline Depths & TSN (transect means) & TSN (transect means) & TSN difference & Percentage \\
\hline $\mathrm{cm}$ & Mg ha $^{-1}$ layer $^{-1}$ & Mg ha $^{-1}$ layer $^{-1}$ & \multicolumn{2}{|c|}{$\mathrm{Mg} \mathrm{ha}^{-1}$ layer $^{-1}$} \\
\hline & Interfluve (prairie) & \multicolumn{2}{|c|}{ Interfluve (cropland) } & \\
\hline $0-15$ & $5.80 a^{*}$ & $4.27 \mathrm{~b}$ & -1.53 & $-26 \%$ \\
\hline $15-30$ & $4.78 \mathrm{a}$ & 3.95a & -0.83 & $-17 \%$ \\
\hline $30-50$ & 2.40a & $2.97 \mathrm{~b}$ & 0.57 & $24 \%$ \\
\hline \multirow[t]{2}{*}{$0-50$} & $12.99 a$ & $11.18 \mathrm{a}$ & -1.81 & $-14 \%$ \\
\hline & Shoulder (prairie) & Shoulder (cropland) & & \\
\hline $0-15$ & $5.54 \mathrm{a}$ & $3.59 b$ & -1.95 & $-35 \%$ \\
\hline $15-30$ & $4.76 a$ & $2.55 b$ & -2.21 & $-46 \%$ \\
\hline $30-50$ & $3.24 a$ & $3.54 a$ & 0.3 & $9 \%$ \\
\hline \multirow[t]{2}{*}{$0-50$} & $13.53 a$ & $9.68 \mathrm{~b}$ & -3.85 & $-28 \%$ \\
\hline & Backslope (prairie) & Backslope (cropland) & & \\
\hline $0-15$ & $5.37 \mathrm{a}$ & $4.26 \mathrm{~b}$ & -1.11 & $-21 \%$ \\
\hline $15-30$ & $3.81 \mathrm{a}$ & 4.18a & 0.37 & $10 \%$ \\
\hline $30-50$ & $3.35 a$ & $4.08 \mathrm{~b}$ & 0.73 & $22 \%$ \\
\hline \multirow[t]{2}{*}{$0-50$} & $12.53 a$ & $12.52 \mathrm{a}$ & -0.01 & $0 \%$ \\
\hline & Footslope (prairie) & Footslope (cropland) & & \\
\hline $0-15$ & $6.16 \mathrm{a}$ & $5.19 a$ & -0.97 & $-16 \%$ \\
\hline $15-30$ & $4.90 \mathrm{a}$ & 4.13a & -0.77 & $-16 \%$ \\
\hline $30-50$ & $3.90 \mathrm{a}$ & $3.14 \mathrm{a}$ & -0.76 & $-19 \%$ \\
\hline \multirow[t]{2}{*}{$0-50$} & $14.96 \mathrm{a}$ & $12.48 \mathrm{a}$ & -2.48 & $-17 \%$ \\
\hline & Toeslope (prairie) & Toesleope (cropland) & & \\
\hline $0-15$ & $3.71 \mathrm{a}$ & $3.40 \mathrm{a}$ & -0.31 & $-8 \%$ \\
\hline $15-30$ & $3.44 a$ & $2.75 b$ & -0.69 & $-20 \%$ \\
\hline $30-50$ & $3.86 \mathrm{a}$ & $2.82 b$ & -1.04 & $-27 \%$ \\
\hline $0-50$ & $11.01 \mathrm{a}$ & $8.97 a$ & -2.04 & $-15 \%$ \\
\hline
\end{tabular}

*Transect means for different land uses with the same letter and for the same landscape position and depth layer are not significantly different at the 0.05 probability level.

The weight of TSN by the landscape segment width is shown (distance between tick marks in Figure 2) in Table 5. The prairie had $12.9 \mathrm{Mg} \cdot \mathrm{N} \cdot \mathrm{ha}^{-1}$ and the agricultural and had $10.8 \mathrm{Mg} \mathrm{N} \mathrm{Ma}^{-1}$ or $2.1 \mathrm{Mg} \mathrm{N}^{-1}$ or $19 \%$ less TSN. The prairie site may have been pastured and later burned, but not cultivated (Figure 3), between 1945 and 1971 when in private use. The loss was most likely a result of intensive grazing, the disturbance as a result of fire and subsequent soil erosion. The C:N ratio for all landscape positions at prairie is 12.4 to 1 and for the cropland the $\mathrm{C}: \mathrm{N}$ ratio was 12.2 to 1 . If only the eroding landscapes are included the cropland would have lost $12 \%$ instead of $16 \%$ of TSN stock. Apparently more TSN is retained on the toeslope than SOC.

Table 6 provides the fly ash content in $\mathrm{g}^{-\mathrm{m}^{-2}}$.layer ${ }^{-1}$ for the $0-15,15-30,30-50$, and 0 - $50 \mathrm{~cm}$ layers. The mean fly ash content for the interfluve was used as a baceline to calculate erosion from cropland landscape positions. Table 6 shows the backslope and footslope had the highest soil erosion rate (17 $\left.\mathrm{Mt} \mathrm{ha}^{-1} \mathrm{yr}^{-1}\right)$ for the prai- 
Table 4. Prairie and agricultural land SOC for $0.5 \mathrm{~m}$ layer and by landscape position and represent the mean of two transects.

\begin{tabular}{cccccc}
\hline Position & Landscape segment & Landscape fractional & SOC stock & Loss of SOC & Percentage \\
\hline & width (m) & segment width as & landscape & stock & change \\
\hline Prairie & decimal & Mg C ha $^{-1}$ & Mg C ha $^{-1}$ & \\
Interfluve & $23.7 \mathrm{a}^{*}$ & & & \\
Shoulder & $20.0 \mathrm{a}$ & $0.205 \mathrm{a}$ & $31.8 \mathrm{a}$ & \\
Backlslope & $23.9 \mathrm{a}$ & $0.173 \mathrm{a}$ & $31.8 \mathrm{a}$ & \\
Footslope & $20.9 \mathrm{a}$ & $0.206 \mathrm{a}$ & $26.0 \mathrm{a}$ & \\
Toeslope & $27.3 \mathrm{a}$ & $0.180 \mathrm{a}$ & $30.3 \mathrm{a}$ & \\
Total & $115.8 \mathrm{a}$ & $0.236 \mathrm{a}$ & $40.8 \mathrm{a}$ & \\
Total without toeslope & & $1.000 \mathrm{a}$ & $160.6 \mathrm{a}$ & \\
Cultivated agricultural land & & & $119.8 \mathrm{a}$ & \\
Interfluve & $22.5 \mathrm{a}$ & & & \\
Shoulder & $14.6 \mathrm{~b}$ & $0.237 \mathrm{a}$ & $32.3 \mathrm{a}$ & \\
Backlslope & $15.6 \mathrm{~b}$ & $0.153 \mathrm{a}$ & $18.7 \mathrm{~b}$ & \\
Footslope & $16.9 \mathrm{~b}$ & $0.164 \mathrm{~b}$ & $24.2 \mathrm{a}$ & \\
Toeslope & $25.4 \mathrm{a}$ & $0.178 \mathrm{a}$ & $26.9 \mathrm{a}$ & \\
Total & $95.0 \mathrm{~b}$ & $0.267 \mathrm{a}$ & $29.5 \mathrm{~b}$ & \\
Total without toeslope & & $1.000 \mathrm{a}$ & $131.6 \mathrm{a}$ & 29.0 \\
\hline
\end{tabular}

*Transect means for different land uses with the same letter and for the same landscape position and depth layer are not significantly different at the 0.05 probability level.

Table 5. Prairie and agricultural land TSN for $0.5 \mathrm{~m}$ layer and by landscape position and represent the mean of two transects.

\begin{tabular}{ccccc}
\hline Position & Landscape segment & Landscape fractional & TSN stock & Loss of TSN Percentage \\
\hline & width (m) & segment width as & in landscape & stock \\
\hline Prairie & & & & \\
Interfluve & $23.7 \mathrm{a}^{*}$ & $0.205 \mathrm{a}$ & $2.66 \mathrm{a}$ & \\
Shoulder & $20.0 \mathrm{a}$ & $0.173 \mathrm{a}$ & $2.44 \mathrm{a}$ & \\
Backlslope & $23.9 \mathrm{a}$ & $0.206 \mathrm{a}$ & $2.03 \mathrm{a}$ & \\
Footslope & $20.9 \mathrm{a}$ & $0.180 \mathrm{a}$ & $2.70 \mathrm{a}$ & \\
Toeslope & $27.3 \mathrm{a}$ & $0.236 \mathrm{a}$ & $3.20 \mathrm{a}$ & \\
Total & $115.8 \mathrm{a}$ & $1.000 \mathrm{a}$ & $13.03 \mathrm{a}$ & \\
Total without toeslope & & & $9.83 \mathrm{a}$ & \\
Cultivated agricultural land & & & & \\
Interfluve & $22.5 \mathrm{a}$ & $0.237 \mathrm{a}$ & $2.64 \mathrm{a}$ & \\
Shoulder & $14.6 \mathrm{~b}$ & $0.153 \mathrm{a}$ & $1.49 \mathrm{~b}$ & \\
Backlslope & $15.6 \mathrm{~b}$ & $0.164 \mathrm{~b}$ & $2.06 \mathrm{a}$ & \\
Footslope & $16.9 \mathrm{~b}$ & $0.178 \mathrm{a}$ & $2.22 \mathrm{~b}$ & \\
Toeslope & $25.4 \mathrm{a}$ & $0.267 \mathrm{a}$ & $2.39 \mathrm{~b}$ & $17 \%$ \\
Total & $95.0 \mathrm{~b}$ & $1.000 \mathrm{a}$ & $10.80 \mathrm{~b}$ & 2.23 \\
Total without toeslope & & & $8.41 \mathrm{~b}$ & 1.42 \\
\hline
\end{tabular}

*Transect means for different land uses with the same letter and for the same landscape position and depth layer are not significantly different at the 0.05 probability level. 
Table 6. Fly ash content summary of data for the sloping prairie and the adjacent cultivated cropland. Representative pedons were sampled to $0.5 \mathrm{~m}$ depth on each landscape position and transect.

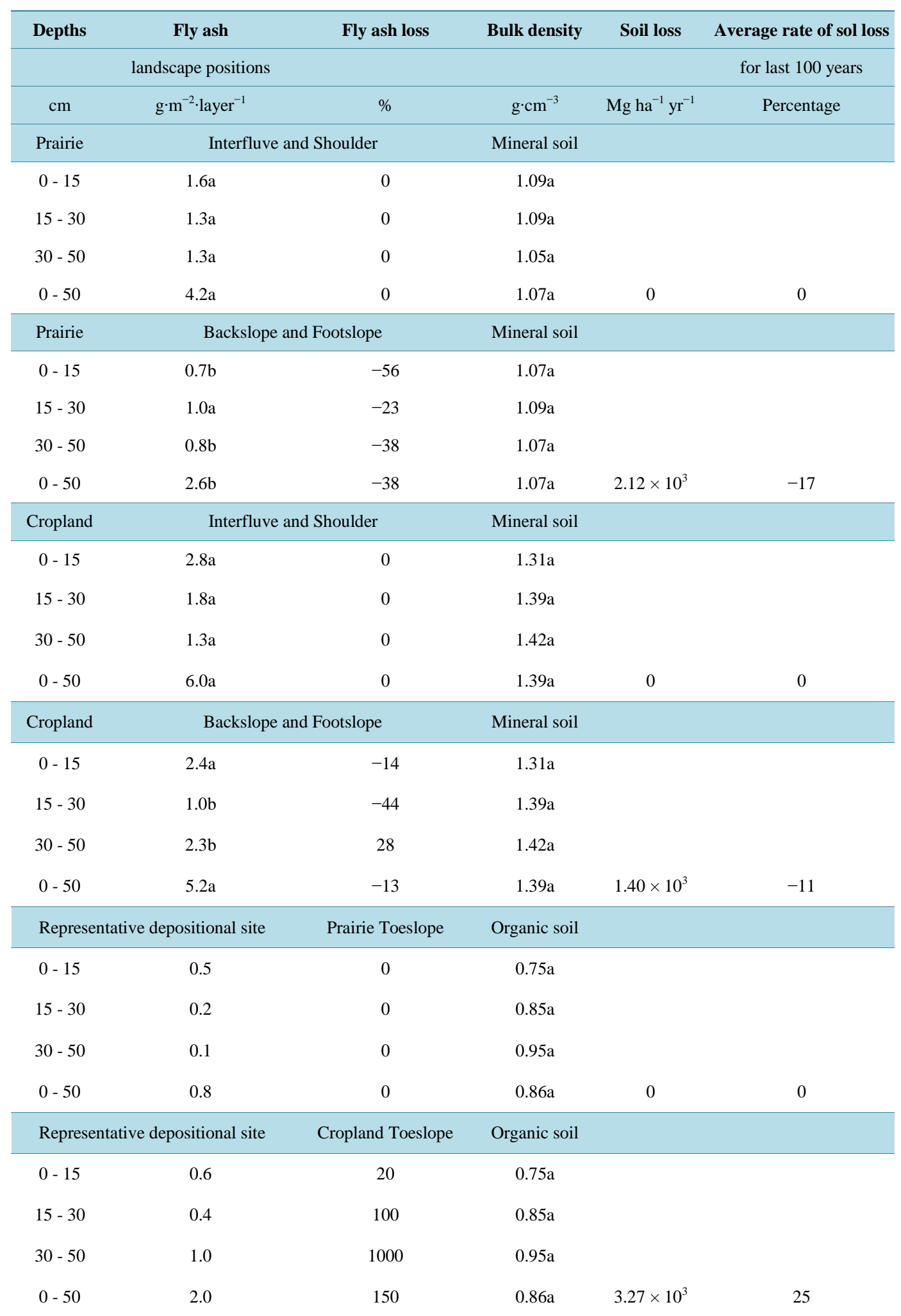

${ }^{*}$ Transect means for different land uses with the same letter and for the same landscape position and depth layer are not significantly different at the 0.05 probability level. 
rie based on fly ash content. These backslope and footslope erosion rates would not have occurred if the prairie had not been intensively pastured and periodically burned. The erosion rate on the cropland was higher as expected. However, as a result of high concentrations of fly ash in the agricultural land backslope soil the erosion rate as only $11 \mathrm{Mg} \mathrm{ha}^{-1} \mathrm{yr}^{-1}$ versus the prairie backslope rate of $21 \mathrm{Mg} \mathrm{ha}^{-1} \mathrm{yr}^{-1}$. It appears that even with a slope of $6 \%$ there was $30 \mathrm{~cm}$ of deposition on top of the original soil surface which was unexpected. The backslope original surface soil was covered with sediment in the last 130 years. The SOC data for the $30-50 \mathrm{~cm}$ (Table 1) layer of the cropland backslope supports the hypotheses that sediment buried the original horizon surface soil. The SOC stock is $16 \%$ above the prairie backslope and a similar comparison of the shoulder and footslope had the more typical $6 \%$ to $13 \%$ less SOC levels. The interfluve at agricultural land site also appears to have an increase in SOC stocks in the $30-50 \mathrm{~cm}$ layer which also suggests the original surface was buried by deposition and that could explain why the $30-50 \mathrm{~cm}$ layer had more fly ash than anticipated for the interfluve and compared to prairie shoulder, backslope and footslope. Fly ash data (Table 6) for a representative prairie and cropland depositional toeslope was included to determine if sediment deposition was occurring in the cropland but not in the prairie. As a result of deposition the fly ash content of the cropland toeslope was $1.2 \mathrm{~g} \cdot \mathrm{m}^{-2}$ higher than prairie toeslope for the $50 \mathrm{~cm}$ thick layer.

\section{Discussion}

As a result of the prairie being in the public lands section the native prairie area was protected from cultivation for all but 26 years. During those 26 years, 1945 to 1971, in private ownership the transect area was subjected to intensive grazing but was never cultivated. After 1978 the transect area was periodically burned until 1983 in an attempt to control invasive plant species. This prairie study results was used to determine baseline SOC and TSN storage for prairie landscapes in South Dakota and can be used to evaluate the effects of any future land use changes, as a result of climate change, on SOC and TSN storage and retention. There was a lack of reliable SOC and TSN data baseline data for current prairie lands and if future land use changes were to occur there is a need for such baseline data to determine the effects of land use change and erosion on SOC and TSN stocks and future greenhouse gas emissions.

Assuming the mesic-frigid temperature line in the US moved north as a result of climate shift, previously South Dakota prairie would be cultivated. If cultivation happened during the next 100 years, as a result of the longer growing season and greater temperatures or growing degree days, then this land use change would result in $\mathrm{CO}_{2}$ and $\mathrm{N}_{2} \mathrm{O}$ transferred to atmosphere (or leached in case of $\mathrm{N}$ ) from the current soil storage as a result of the farming, transported eroded soil as sediment to lower landscape positions, the water, or the atmosphere or leached in the case of $\mathrm{N}$. If in the future the prairie lands were converted to cropland use the decomposition caused by cultivation will result in at least a $18 \%$ to $16 \%$ loss of $\mathrm{C}$ and $\mathrm{N}$, respectively, to atmosphere as $\mathrm{CO}_{2}$ and $\mathrm{N}$ or $\mathrm{N}_{2} \mathrm{O}$. During the next 130 years of cultivation it appears that approximately $30 \%$ of the SOC and TSN in transported sediment will be lost to atmosphere and water. Since up to $70 \%$ of the eroded soil mass with attached SOC and TSN stock would be retained on the lower segments of the landscape the SOC and TSN should be retained on the lower landscape segments for many more years. This projected land use conversion from prairie to cropland as a result of climate shift would result in greater greenhouse gas emissions as a result of reduced SOC and TSN stocks in the landscape than if the area stayed as prairie. Spatial and temporal climate change is likely to result in land cover and use shifts depending on temperature and precipitation patterns. Crop production may decline in some areas and expand in others. Examples of these areas include the prairie pothole region of the northern plains.

In the northern US prairie pothole region, cropland acres are likely to increase as wetlands diminish and temperatures increase. This region includes the division between the North American mesic-frigid soil temperature regimes. As a result, prairie and prairie pothole lands currently in the frigid temperature regime may be converted to cropland, pasture and grazing land. Row crop production may expand northward to meet demands for corn, wheat and forage production. Expansions of corn, wheat and forage production have currently been observed in the frigid temperature regime of North and South Dakota.

Temporal and spatial changes in precipitation and temperature patterns can alter the soil carbon and nitrogen dynamics, which has a significant impact on carbon sequestration, storage, retention and loss as well as greenhouse gas release. This in turn affects management techniques because practices that have been used to maximize efficiency may no longer deliver similar results. 


\section{Conclusion}

At the prairie site more past soil erosion as a result of 26 years of intensive grazing and 5 years of periodic burning to control invasive plant species, occurred more than expected based on fly ash concentration on the shoulder, backslope and footslope. The prairie was pastured for 26 years but never cultivated, and it was subjected to periodic burning and subsequent soil erosion. The erosion rates at the backslope and footslope of the prairie site were $17 \mathrm{Mt} \mathrm{ha}^{-1} \mathrm{yr}^{-1}$ which should not have occurred if it had remained in prairie during the last 100 years. The erosion rates at the cropland backslope and footslope were $11 \mathrm{Mt} \mathrm{ha}^{-1} \mathrm{yr}^{-1}$ which was slower than the similar landscape positions on the prairie. The SOC and TSN stocks of the agricultural land had $29.0 \mathrm{Mg} \mathrm{C}$ ha $^{-1}$ less (18\%) SOC and $1.31 \mathrm{Mg} \mathrm{C} \mathrm{ha}^{-1}$ less (16\%) TSN in 2011. These differences represent a predictor of the SOC and TSN loss that would occur if the prairie was cultivated for the next 100 years as a result of climate shift and the mesic-frigid line moving north.

\section{Acknowledgements}

This paper is published with the approval of the Director of the Illinois Office of Research, Urbana, IL, and funded by the US Civilian Research and Development Foundation and Russian Foundation as part of a linkage grant (CRDF RUG1-2948-MO-09) between Moscow State University and University of Illinois at Urbana-Champaign. Additional funds for this work were provided by the Russian Foundation for Basic Research (Project \# 07-05-00234). Additional funds part of Regional Research Project no. 15-372 and in cooperation with North-Central Regional Project No. NC-1178 Soil Carbon Sequestration (formerly NC-174 Soil Erosion Productivity).

\section{References}

[1] Six, J., Elliott, E.T., Paustaina, K. and Doran, J.W. (1998) Aggregation and Soil Organic Matter in Cultivated and Native Grassland Soils. Soil Science Society of America Journal, 62, 1367-1373. http://dx.doi.org/10.2136/sssaj1998.03615995006200050032x

[2] Davidson, I. and Ackerman, L. (1993) Changes in Soil Carbon Inventories Following Cultivation of Previously Untilled Soils. Biogeochemistry, 20, 161-193. http://dx.doi.org/10.1007/BF00000786

[3] Van Oost, K., Quine, T.A.G., Govers, S., De Gryze, J., Six, J.W., Harden, J.C., Ritchie, G.W., McCarty, G., Hechrath, C., Kosmas, J.V., Giraldez, J.R., da Silva, M. and Merchx, R. (2007) The Impact of Agricultural Soil Erosion on the Global Carbon Cycle. Science, 318, 626-629. http://dx.doi.org/10.1126/science.1145724

[4] Lal, R. (2003) Soil Erosion and the Global Carbon Budget. Environmental International, 29, 437-450. http://dx.doi.org/10.1016/S0160-4120(02)00192-7

[5] Gregorich, E.G., Greer, K.J., Anderson, D.W. and Liang, B.C. (1998) Carbon Distribution and Losses: Erosion and Depositional Effects. Soil and Tillage Research, 47, 291-302. http://dx.doi.org/10.1016/S0167-1987(98)00117-2

[6] Vanden Bygaart, A.J. (2001) Erosion and Deposition History Derived by Depth-Stratigraphy of 137 Cs and Soil Organic Carbon. Soil and Tillage Research, 61, 187-192. http://dx.doi.org/10.1016/S0167-1987(01)00203-3

[7] Janzen, H.H., Campbell, C.A., Izzaurralde, R.C., Ellert, B.H., Juma, N., McGill, W.B. and Zentner, R.P. (1998) Management Effects on Soil C Storage on the Canadian Prairies. Soil and Tillage Research, 47, 181-195. http://dx.doi.org/10.1016/S0167-1987(98)00105-6

[8] Vanden Bygaart, A.J., Yang, X.M., Kay, B.D. and Aspinall, J.D. (2002) Variability in Carbon Sequestration Potential in No-Till Soil Landscapes of Southern Ontario. Soil and Tillage Research, 65, 231-241. http://dx.doi.org/10.1016/S0167-1987(02)00003-X

[9] Olson, K.R., Gennadiyev, A.N., Jones, R.L. and Chernyanskii, S. (2002) Erosion Patterns on Cultivated and Forested Hillslopes in Moscow Region, Russia. Soil Science Society of America Journal, 66, 193-201. http://dx.doi.org/10.2136/sssaj2002.0193

[10] Olson, K.R., Jones, R.L., Gennadiyev, A.N., Chernyanskii, S., Woods, W.I. and Lang, J.M. (2003) Soil Catena Formation and Erosion of two Mississippian Mounds at Cahokia Archaeological Site, Illinois. Soil Science, 168, 812-824.

[11] Shukla, M.K. and Lal, R. (2005) Erosion Effects on Soil Organic Carbon Stock of Six Miamian Soils in West Central Ohio. Soil and Tillage Research, 81, 173-181. http://dx.doi.org/10.1016/j.still.2004.09.006

[12] Tiessen, H., Stewart, W.B. and Betany, J.R. (1982) Cultivation Effects on the Amounts and Concentration of C, N, and P in Grassland Soils. Agronomy Journal, 74, 831-835. http://dx.doi.org/10.2134/agronj1982.00021962007400050015x

[13] McGill, W.B., Dormaar, J.F. and Reinl-Dwyer, E. (1988) New Perspectives on Soil Organic Matter Quality, Quantity, 
and Dynamics on the Canadian Prairies. In: Proceedings of Canadian Society of Soil Science and Canadian Society of Extension. Joint Symposium, Land Degradation: Assessment and Insight into a Western Canadian Problem. Calgary, Canada, 23 August 1988, 30-48.

[14] Bowman, R.A., Reeder, R.J. and Laber, W.R. (1990) Changes in Soil Properties in a Central Plains Rangeland Soil after 3, 20 and 60 Years of Cultivation. Soil Science, 150, 851-857. http://dx.doi.org/10.1097/00010694-199012000-00004

[15] Malhi, S.S., Brandt, S. and Gill, K.S. (2003) Cultivation and Grassland Type Effects on Light Fraction and Total Organic C and N in a Dark Brown Chernozemic Soil. Canadian Journal of Soil Science, 83, 145-153. http://dx.doi.org/10.4141/S02-028

[16] Campbell, C.A. and Souster, W. (1982) Loss of Organic Matter and Potential Mineralizable Nitrogen from Saskatchewan Soils Due to Cropping. Canadian Journal of Soil Science, 62, 651-656. http://dx.doi.org/10.4141/cjss82-071

[17] Mann, L.K. (1985) A Regional Comparison of Carbon in Cultivated and Uncultivated Alfisols and Mollisols in Central United States. Geoderma, 36, 241-253. http://dx.doi.org/10.1016/0016-7061(85)90005-9

[18] Mann, L.K. (1986) Changes in Soil Carbon Storage after Cultivation. Soil Science, 142, 279-288. http://dx.doi.org/10.1097/00010694-198611000-00006

[19] Schimel, D.S. (1986) Carbon and Nitrogen Turnover in Adjacent Grassland and Cropland Ecosystems. Biogeochemistry, 2, 345-357. http://dx.doi.org/10.1007/BF02180325

[20] Johnson, M.G. and Kern, J.S. (1991) Sequestering Carbon in Soils: A Workshop to Explore the Potential for Mitigating Global Climate Change. USEPA Environmental Research Laboratory, Corvallis.

[21] Rasmussen, P.E. and Parton, W.J. (1994) Long-Term Effects of Residue Management in Wheat-Fall: I. Inputs, Yield and Soil Organic Matter. Soil Science Society of America Journal, 58, 523-530. http://dx.doi.org/10.2136/sssaj1994.03615995005800020039x

[22] Houghton, R.A. (1995) Changes in Storage of Terrestrial Carbon since 1850. In: Lal, R., Kimble, J., Levine, E. and Stewart, B.A., Eds., Soils and Global Change, CRC/Lewis Publishers, Boca Raton.

[23] Kern, J.S. (1994) Spatial Patterns of Soil Organic Carbon in the Contiguous United States. Soil Science Society of America Journal, 58, 439-455. http://dx.doi.org/10.2136/sssaj1994.03615995005800020029x

[24] Lal, R., Kimble, J.M., Follet, R.F. and Cole, C.V. (1998) The Potential of U.S. Cropland to Sequester Carbon and Mitigate the Greenhouse Effect. Ann Arbor Press, Chelsea.

[25] Food and Agriculture Organization (FAO) (2001) Soil Carbon Sequestration for Improved Land Management. World Resource. Food and Agriculture Organization for the United Nations, 62.

[26] Lal, R. (1995) Global Soil Erosion by Water and Carbon Dynamics. In: Lal, R., Kimble, J.M., Levine, E. and Stewart, B.A., Eds., Soils and Global Change, CRC/Lewis Publishers, Boca Raton, 131-142.

[27] Schumacher, T.E., Lindstrom, M.J., Schumacher, J.A., Reicosky, D.C. and Malo, D.D. (2003) Carbon Distribution in a Hummocky Landscape: An Estimate of Surface Translocation by Tillage and Water. Soil Water Conservation Society Program Abstracts, 75.

[28] Schumacher, T.E., Lindstrom, M.J., Schumacher, J.A. and Lemme, G.D. (1999) Modeling Spatial Variation in Productivity Due to Tillage and Water Erosion. Soil and Tillage Research, 51, 331-339. http://dx.doi.org/10.1016/S0167-1987(99)00046-X

[29] Malo, D.D., Schumacher, T.E. and Doolittle, J.J. (2005) Long-Term Cultivation Impacts on Selected Soil Properties in the Northern Great Plains. Soil and Tillage Research, 81, 277-291. http://dx.doi.org/10.1016/j.still.2004.09.015

[30] Farenhorst, A., Papiernik, S.K., Saiyed, I., Messing, P., Stephens, K.D., Schumacher, J.A., Lobb, D.A., Li, S., Lindstrom, M.J. and Schumacher, T.E. (2008) Herbicide Sorption Coefficients in Relations to Soil Properties and Terrain Attributes on a Cultivated Prairie. Journal of Environmental Quality, 37, 1201-1208. http://dx.doi.org/10.2134/jeq2007.0109

[31] Schumacher, J.A., Kaspar, T.C., Ritchie, J.C., Schumacher, T.E., Karlen, D.L., Venteris, E.R., McCarty, G.W., Colvin, T.S., Jaynes, D.B., Lindstrom, M.J. and Fenton, T.E. (2005) Identifying Spatial Patterns of Erosion for Use in Precision Conservation. Journal of Soil and Water Conservation, 60, 355-362.

[32] Alba-De, S., Lindstrom, M., Schumacher, T.E. and Malo, D.D. (2004) Soil Landscape Evolution Due to Soil Redistribution by Tillage: A New Conceptual Model of Soil Catena Evolution in Agricultural Landscapes. Catena, 58, 77-100. http://dx.doi.org/10.1016/j.catena.2003.12.004

[33] Olson, K.R., Jones, R.L., Gennadiyev, A.N., Chernyanskii, S.S., Woods, W.I. and Lang, J.M. (2006) Fly-Ash Distributions to Assess Erosion and Deposition in Illinois Landscapes. Soil and Tillage Research, 89, 155-166. http://dx.doi.org/10.1016/j.still.2005.07.007

[34] Olson, K.R., Gennadiyev, A.N. and Golosov, V.N. (2008) Comparison of Fly-Ash and Radio-Cesium Tracer Methods 
to Assess Soil Erosion and Deposition in Illinois Landscapes (USA). Soil Science, 173, 575-586. http://dx.doi.org/10.1097/SS.0b013e318182b094

[35] Olson, K.R., Gennadiyev, A.N., Zhidkin, A.P. and Markelov, M.V. (2011) Impact of Land Use Change and Soil Erosion in Upper Mississippi River Valley on Soil Organic Carbon Retention and Greenhouse Gas Emissions. Soil Science, 176, 449-458. http://dx.doi.org/10.1097/SS.0b013e3182285cde

[36] Olson, K.R., Gennadiyev, A.N., Zhidkin, A.P., Markelov, M.V., Golosov, V.N. and Lang, J.M. (2013) Use of Magnetic Tracer and Radio-Cesium Methods to Determine Past Cropland Soil Erosion Amounts and Rates. Catena, 104, 103-110. http://dx.doi.org/10.1016/j.catena.2012.10.015

[37] Olson, K.R., Gennadiyev, A.N., Kovach, R.G. and Lang, J.M. (2013) The Use of Fly Ash to Determine the Extent of Sediment Transport on Nearly Level Western Illinois Landscapes. Soil Science, 178, 24-28. http://dx.doi.org/10.1097/SS.0b013e318284b5cd

[38] Gennadiyev, A.N., Golosov, V.N., Chernyanskii, S.S., Markelov, M.V., Olson, K.R., Kovach, R.G. and Belyaev, V.R. (2005) The Concurrent Use of Radioactive and Magnetic Tracers for Soil Erosion Quantification. Eurasian Soil Science, 38, 954-965.

[39] Olson, K.R., Gennadiyev, A.N., Zhidkin, A.P. and Markelov, M.V. (2012) Impact of Land Use Change, Slope and Erosion on Soil Organic Carbon Retention and Storage USA. Soil Science, 177, 269-278. http://dx.doi.org/10.1097/SS.0b013e318244d8d2

[40] Ode, D. (1978) The Nature Conservancy Preserves Master Plan for the Sioux Prairie, South Dakota Chapter.

[41] Soil Survey Staff (2004) Soil Survey Laboratory Methods Manual. Soil Survey Investigations Report No.42, Version 4.0. National Soil Survey Center, NRCS, USDA, Lincoln.

[42] Jones, R.L. and Olson, K.R. (1990) Fly Ash Use as a Time Marker in Sedimentation Studies. Soil Science Society of America Journal, 54, 855-859. http://dx.doi.org/10.2136/sssaj1990.03615995005400030040x

[43] SAS Institute (2002) SAS/STAT Guide for Personal Computers. Version 6, SAS Institute, Cary.

[44] Welbon, C. (1978) Soil Survey of Sioux Prairie. Soil Conservation Service, Flandreau. 